\title{
The Effect of Leadership Styles of Administrative Leaders on Job Performance Behavior among Staff of Najran University
}

\author{
Fuad S. Alkhasawneh \\ Assist. Professor of Educational Administration, Najran University
}

Received: Nov. 24, 2017 Accepted: Feb. 23, 2018 Published: February 23, 2018

doi:10.5296/jse.v8i1.12762 URL: https://doi.org/10.5296/jse.v8i1.12762

\begin{abstract}
The present study is an attempt to investigate the effect of leadership styles of administrative leaders on job performance behavior among staff of Najran University. To achieve the objective of the study, the sample was randomly selected of (117) administrative staff at Najran University. The descriptive approach was adopted in this study, in which the author designed 36-item questionnaire divided into two sections: the first one is leadership style (25) items distributed to three domains (autocratic leadership style, participative leadership style and bureaucratic leadership style), and the second section is job performance (11) items. The questionnaire was applied to the participants after verification of validity and reliability. The study revealed that participative style was high, autocratic style was moderate and bureaucratic style was low. The results showed that there are statistically significant differences in autocratic style $(\mathrm{a}=0.05)$ due to gender in favor of females, while there are statistically significant differences in participative style in favor of males, and no statistically significant differences due to scientific qualification. The results indicated that there are positive correlation between the participative style and job performance and negative correlation between the autocratic style and job performance. The author recommends adopting the participative leadership style in administration due to the positive effects it has on job performance, as well as conducting studies on the common leadership styles in other Saudi universities.
\end{abstract}

Keywords: leadership styles, job performance 


\section{Introduction}

Lately, many countries have paid great attention to leadership because of its significant role in improvement, development and progress. Leadership, as a branch of human knowledge, is the key to the future in any organization. In other words, without it, organizations can't move to the future because the administrative work focuses on finding solutions to problems, keeping up with updates and facing challenges.

Like administration, leadership is a science and art. Undoubtedly, the success in making and implementing the plans and the administrative policies can't be accomplished but with the guidance of the wise administrative leaders and state control. Accordingly, successful leadership is a basis for any organization. It is one of the most significant phenomena of social interaction because leaders play a key role in it by affecting the guidance of the group's activity, production and the spirit dominating its members (Hasan, 2004).

Leadership is a social effect on the process in which the human seeks to achieve certain objectives with subordinates (Omolayo, 2007), or it is the coordination, organization and guidance of efforts to achieve the previously set objectives through the effective participation by the employees (Mullins, 2004).

It is an important issue because it is the effective tool to accomplish the tasks and objectives of the administrative institutions. That is, the success or failure of these institutions relays on the success achieved by the administrative leaders by performing their assigned tasks and roles and contributing to the development of their organizations according to their abilities and readiness to affect others in order to achieve these objectives (Wippy, 2001).

According to Schein (2011), the administrative styles contribute to guiding the behavior of workers in the work environment, within the various organizational circumstances, and to increasing the effectiveness of performance, especially when they feel that the leadership respects their opinions and motivates them to achieve the aspired objectives according to their abilities and readiness to affect others in order to achieve these objectives.

Furthermore, Khidr (2009) argues that the traditional leadership that affirms following the hierarchy may be an obstacle to the progress and development of organizations. It sticks to job hierarchy which wastes time, hinders the smoothness the flow of information and makes it unavailable to all. Additionally, it sticks to the old measures and refuses change because it does not use openness, transparency and modern administrative thought. Elsaedy (2006) reported that leadership problems and the lack of its characteristics impede organizational learning. Leadership can affect two trends: quantitative and qualitative.

The same was reported by Whitaker (2001) stressing that the effective leadership empowers employees, relays on applying the principles of transformative and collaborative leadership, adopts making the cooperative decision and develops the creativity among the employees.

The distinguished leadership plays an effective role that affects the activities of the organization to contribute to creating the appropriate organizational atmosphere that affects the employees' satisfaction. Accordingly, it contributes to providing the administrative 
environment that helps achieve the individual, group and organizational objectives. It impacts the effectiveness or performance of individuals, groups and the whole organization (Zhang and Li, 2013).

The various leadership styles impact the effectiveness or the organizational performance. That is, the leadership style is a strong indicator of the job satisfaction and performance. For example, the participative style contributes to fostering the employee's performance and self-trust, while the bureaucratic one negatively affects the employees' performance and motivates them to feel that it is a tool to implement the administrative decisions, affecting performance and depriving the institution of their creative energies (Nanjund \& Swamy, 2014).

Organizations need active leaders who are able to handle the international environmental complexities that change fast, need to resolve the institutional conflicts and communicate and make decisions based on the necessary work requirements. Accordingly, the various leadership styles may affect the core of the administrative process. Additionally, its significance and role are based on playing a key role that affects the elements of the administrative process to make the administration more dynamic and effective and work as a motive to achieve its objectives (Lu, Junye and Yan, 2011).

The participative leadership style is one of the best styles which cares for the subordinates. While some authors called it the consultative or human leadership, others adopted the term positive leadership. That is, it is a social process in which the group controls itself. The leader motivates the members to compete and collaborate, shares the opinion and consultation with them regarding what shall be done, commits to the goals of the group, allows the group freedom to distribute work and is objective in praise and criticism to the members who feel the importance of their positive contribution and are more cohesive (Elsakarna, 2010).

In this style, employees enjoy the freedom of action, thinking and expressing opinions at ease. It creates cohesion among them because of the care and interest it provides to make everyone feels that $\mathrm{s}$ /he is an effective member of the group. In other words, $\mathrm{s} /$ he works with, not for, the leader. That is, the leader asks the group for their opinions and encloses them in decision making (Kanan, 2009).

In contrast, the autocratic leadership style focuses on the authorities of the leader, where employees only implement the leader's decision with all details. Their performance is measured by complete obedience to the leader and literal implementation of orders (Tema, 2006). Whereas in the bureaucratic leadership style, employees' performance is mainly characterized by routine. That is, the instructions are made according to the central hierarchy of authorities (Elalaq, 2009). Therefore, the present study investigates the effect of leadership styles of administrative leaders on job performance behavior among the staff of Najran University.

\section{Statement of the problem}

Universities are keen on defining the quality and quantity of their staff to investigate strengths and weaknesses at the performance level to achieve the competitive advantage, but 


\section{Macrothink

without affecting job performance positively or negatively because of the permanent leadership style. Hence, the problem of the present study has been defined in answering the following questions:

A. What is the leadership style among the administrative leaders at Najran University?

B. Are there statistically significant differences at the level of $(\alpha=0.05)$ on the leadership styles among the administrative leaders at Najran university according to gender?

C. Are there statistically significant differences at the level of $(\alpha=0.05)$ on the leadership styles among the administrative leaders at Najran university according to scientific qualification?

D. Is there a correlation between the style and effect of leadership on the job performance behavior of the staff?

\section{Objectives}

The study aims to:

1. Investigate the nature of the leadership style among the administrative leaders at Najran University.

2. Show the differences in the nature of the administrative style among the administrative leaders at Najran University according to gender and scientific qualification.

3. Reveal the relationship between the nature of the leadership style and job performance among the administrative leaders at Najran university's staff.

\section{Significance}

The present study is significant because it reveals the nature of relationship between the leadership style and job performance level.

1- It motivates to adopt the administrative style that positively affects the job performance to achieve the competitive advantage of the universities.

2- It provides scientific information on the importance and the direct effect of the administrative style on job performance. Accordingly, it helps them adopt administrative styles that positively affect the performance of the staff to decrease the circulation of staff at universities and achieve a high competitive level in this vital sector.

\section{Limitations}

The present study was limited to the following:

- A sample of the administrators of Najran University in 2017. 
- The author adopts one tool only (i.e. a questionnaire of the administrative type and job performance).

\section{Review of Literature}

Because of the importance of administrative styles and their relationships to performance, many studies were conducted on the topic. Elsherief (2004) aims to reveal the relationship between the administrative types and job performance in the Emirate of Makkah. To achieve its objectives, a sample was randomly selected from (240) administrative manager and head of departments in the Emirate of Makkah. Results revealed that the three leadership styles (democratic, free and autocratic) varied. While the democratic style was high, the free style was average and bureaucratic style was low. Additionally, there is a positive correlation between the democratic style and job performance, while there was a negative correlation between the free and autocratic leadership styles and job performance.

Naser (2010) aimed to identify the leadership styles and their relationship to job performance among the staff of the Palestinian private institutions. This study was applied to a sample of (340) managers and head of department. Its results revealed that the democratic leadership style was ranked first, while the free one was ranked second, and the autocratic leadership style was ranked last. Additionally, there is a positive relationship between the democratic and free styles and job performance, but there is a negative correlation between the autocratic leadership style and job performance.

Raja (2012) aimed to identify the effect and style of leadership on job performance in the higher and middle administration levels in Pakistan service sector firms. In order to collect data, a structured questionnaire was applied to (150) employees in service sector. Results revealed that inspirational motivation, idealized influence, individual consideration and intellectual stimulation guide the employee and leads to higher employee work engagement.

Yang (2012) conducted a study to know the impact of the participative leadership style on job satisfaction and organizational commitment in a number of public relations organizations in Taiwan. A sample of (600) employees from (59) companies in Taipei was randomly selected. Regression analysis showed that the aspects of participative leadership style impact the levels of job satisfaction of public relations employees. Furthermore, Job satisfaction motivated organizational commitment among them under the participative leadership style. The results of the study are an administrative reference to authors and managers in the modern participative leadership.

Aslem (2013) aimed to identify the relation between the administrative styles and job satisfaction among the faculty of Community Colleges in Gaza. This study was applied to (202) administrators. It concluded that the democratic style was average. It was followed by the autocratic and chaotic leadership styles. Furthermore, there was a positive relationship between the democratic leadership style and job satisfaction, while there was a negative correlation between the autocratic leadership style and performance. There was no correlation between the chaotic leadership style and job performance. 


\section{Al Macrothink}

Literature reveals that there was a direct relation between the nature of the leadership style and job performance. Additionally, there were various methods adopted. However, the questionnaire was mostly used to collect data. The present study adds to literature. However, it aims to reveal the relation between the nature of leadership styles and job performance at Najran University because universities are the highest level of administrative development, seeking to achieve excellence and competitiveness.

\section{Methodology}

\section{Method}

The present study adopted the descriptive and analytical approach that studies a phenomenon, event or issue to obtain information that answers the questions of the study.

\section{Population \& Sampling:}

The population of the study comprised the male and female administrators at Najran University in the academic year 1437/ $1438 \mathrm{H}$., numbered (1750). The sample was randomly selected from (117) administrative staff, as shown in table (1).

Table 1. Frequencies and percentages of the dimensions according to the variables

\begin{tabular}{|l|l|l|l|}
\hline \multirow{3}{*}{ Gender } & Categories & Frequency & Percentage \\
\hline \multirow{3}{*}{ Scientific Qualification } & Male & 54 & 0.47 \\
\cline { 2 - 4 } & Female & 63 & 0.53 \\
\cline { 2 - 4 } & Diploma & 44 & 0.38 \\
\cline { 2 - 4 } & Bachelor & 73 & 0.62 \\
\hline & Total & 117 & $100 \%$ \\
\hline
\end{tabular}

\section{Tools of the study}

After reviewing literature, the author designed a 36-item questionnaire divided into two sections: the first one is leadership style (25) items on a five point scale (i.e. Very high, high, average) distributed to sections. The first section was leadership style of (25) items on three domains; the autocratic leadership style covering the items from (1-9), the participative leadership style covering the items from (10-17) and the bureaucratic leadership style covering the items from (18-25). The second section was job performance covering (11) items.

\section{Validity of the tools}

To verify their validity, the tools of the study were displayed to (10) evaluators of Ph.D. holders in measurement, evaluation, public administration and educational administration of the faculty of the Jordanian public universities to make notes and give their opinions. After receiving the questionnaires, they were modified.

\section{Reliability of the tools}

To verify the reliability of the tool, it was verified using test-retest approach by applying the questionnaire and reapplying it after two weeks to a group, not from the sample comprising 


\section{IIMacrothink}

(25) employees. Pearson Correlation Coefficient was calculated based on the scores of the pilot sample in the two times to the whole tool and domains. It ranged from (0.82) to (0.89). Additionally, content validity was estimated using Cronbach's alpha of the domains and the whole tool, ranging (0.75-0.86) that were appropriate to the aims of the study, as shown in table (2).

Table 2. Cronbach Alpha and test-retest reliability of the domains and the whole tool

\begin{tabular}{|l|l|l|}
\hline Domain & Content Validity & Test-Retest Reliability \\
\hline Autocratic leadership style & 0.75 & 0.82 \\
\hline Participative leadership style & 0.80 & 0.87 \\
\hline Bureaucratic leadership style & 0.78 & 0.83 \\
\hline Job performance & 0.86 & 0.89 \\
\hline
\end{tabular}

\section{Variables}

The present study was limited to the following:

I. The main independent variable

1. Gender $\quad \square$ Male $\square$ Female

2. Scientific Qualification: $\square$ Diploma $\square$ Bachelor

II. Dependent Variables

- $\quad$ Leadership styles

- Job performance

\section{Procedures}

To conclude the results of the study, the author conducted the following procedures:

1- Defining the aim of the study to investigate the effect of leadership styles of administrative leaders on job performance behavior among staff of Najran University.

2- $\quad$ Creating tool for the study in the light of related literature and verifying its validity and reliability according to the adopted scientific procedures.

3- Selecting the participants after interviewing and explaining the objectives of the study to them.

4- Distributing the tool to the participants. 
5- $\quad$ Filling in the required data and answering the items with full integrity and objectivity by the participants. They should be informed that their answers are confidential and used for scientific research purposes only.

6- $\quad$ Collecting data and analyzing them using SPSS.

\section{Statistical treatments}

To answer the questions of the study, the following statistical analyses were adopted:

1. To answer the first question, the arithmetic means of the domains and the whole tool were calculated.

2. To answer the second question, T-test was adopted for the effect of gender and scientific qualification.

3. To answer the third question, Pearson Correlation Coefficient was adopted to define the nature of the correlation between the administrative leadership style and job performance behavior. Additionally, three-point scale was adopted to interpret the final results, as shown in table (3).

Table 3. Three-point scale

\begin{tabular}{|l|l|}
\hline From 1 to less than 1.80 & Very low \\
\hline From 1.80 to less than 2.60 & Low \\
\hline From 2.60 to less than 3.40 & Average \\
\hline From 3.40 to less than 4.20 & High \\
\hline From 4.20 to 5.00 & Very high \\
\hline
\end{tabular}

\section{Results}

In this section, the results are discussed, as follows:

A. What is the leadership style among the administrative leaders at Najran university?

In order to answer this question, the means and standard deviations of leadership styles among the administrative leaders at Najran University were calculated, as shown in table (4).

Table 4. Arithmetic means and standard deviations of the leadership styles among the administrative leaders

\begin{tabular}{|l|l|l|l|l|l|}
\hline Rank & No. & \multicolumn{1}{|c|}{ Domain } & Arithmetic mean & Standard deviation & \multicolumn{1}{c|}{ Level } \\
\hline 1 & 2 & Participative leadership style & 4.04 & .995 & High \\
\hline 2 & 3 & Bureaucratic leadership style & 3.87 & .748 & High \\
\hline 3 & 1 & Autocratic leadership style & 3.03 & .693 & $\begin{array}{l}\text { Aver } \\
\text { age }\end{array}$ \\
\hline
\end{tabular}


Table 4 shows that the arithmetic means ranged from (3.03) to (4.04), while the participative style was ranked first with arithmetic mean of (4.04) and a high degree, the autocratic one was ranked last with an arithmetic mean of (3.03) and an average degree. The arithmetic mean of the whole domain was (3.85).

The arithmetic means and standard deviations of the participants' scores in each domain, as follows:

\section{Autocratic leadership style}

Table 5. Arithmetic means and standard deviations of the items of the autocratic style in a descending order

\begin{tabular}{|c|c|c|c|c|c|}
\hline Rank & No. & Items & $\begin{array}{l}\text { Arithm } \\
\text { etic } \\
\text { mean }\end{array}$ & $\begin{array}{l}\text { Standard } \\
\text { deviation }\end{array}$ & Level \\
\hline 1 & 3 & $\begin{array}{l}\text { The administrative leader almost hesitates in making } \\
\text { decisions. }\end{array}$ & 3.34 & .939 & Average \\
\hline 2 & 2 & $\begin{array}{l}\text { The administrative leader seeks to obtain the approval } \\
\text { of the subordinates to his decisions without engaging } \\
\text { them. }\end{array}$ & 3.32 & .889 & Average \\
\hline 3 & 1 & $\begin{array}{l}\text { The administrative leader exploits his authorities to } \\
\text { force his subordinates to perform the work. }\end{array}$ & 3.14 & 1.136 & Average \\
\hline 4 & 4 & $\begin{array}{l}\text { The administrative leader lacks the ability to adapt to } \\
\text { the variables of the internal and external } \\
\text { environments of the university. }\end{array}$ & 3.18 & .837 & Average \\
\hline 4 & 6 & $\begin{array}{l}\text { The administrative leader often holds formal } \\
\text { meetings with the staff to inform them of the work } \\
\text { plans. }\end{array}$ & 3.18 & .887 & Average \\
\hline 6 & 5 & $\begin{array}{l}\text { The administrative leader thinks that the contribution } \\
\text { of the subordinates to work isn't useful. }\end{array}$ & 3.08 & 1.359 & Average \\
\hline 7 & 7 & $\begin{array}{l}\text { The authorities of making decision are in the hands of } \\
\text { the administrative leader only. }\end{array}$ & 2.98 & 1.246 & Average \\
\hline 8 & 8 & $\begin{array}{l}\text { The administrative leader makes many decisions and } \\
\text { instructions to the staff. }\end{array}$ & 2.56 & .933 & Low \\
\hline \multirow[t]{2}{*}{9} & 9 & $\begin{array}{l}\text { The administrative leader often inspects to make sure } \\
\text { that his decisions are implemented without considering } \\
\text { the interests and individual differences of the staff. }\end{array}$ & 2.51 & .988 & Low \\
\hline & & Total & 3.03 & .693 & Average \\
\hline
\end{tabular}

Table 5 shows that the arithmetic means achieved (2.51-3.34), item (3) stating that "the administrative leader almost hesitates in making decisions" was ranked first with a high degree and an arithmetic mean of (3.34). Item (9) stating that "the administrative leader often inspects to make sure that his decisions are implemented without considering the interests and individual differences of the staff" was ranked last with an arithmetic mean of (2.51). The arithmetic mean of the whole domain was (3.03). 


\section{Participative leadership style}

Table 6. Arithmetic means and standard deviations of the items of the participative style in a descending order

\begin{tabular}{|c|c|c|c|c|c|}
\hline Rank & No. & Items & $\begin{array}{l}\text { Arithm } \\
\text { etic } \\
\text { mean }\end{array}$ & $\begin{array}{c}\text { Standar } \\
\mathrm{d} \\
\text { deviati } \\
\text { on }\end{array}$ & Level \\
\hline 1 & 2 & $\begin{array}{l}\text { The managers have a high level of satisfaction with } \\
\text { participative leadership and decision making on a } \\
\text { cooperative basis. }\end{array}$ & 4.21 & .879 & $\begin{array}{l}\text { Very } \\
\text { high }\end{array}$ \\
\hline 2 & 7 & $\begin{array}{l}\text { The administrative leader is keen on conflict } \\
\text { confrontation and resolution in participative methods. }\end{array}$ & 4.13 & 1.071 & High \\
\hline 3 & 8 & $\begin{array}{l}\text { The administrative leader is keen on making the } \\
\text { strategic decisions with engaging the subordinates to } \\
\text { make the ultimate decision. }\end{array}$ & 4.04 & .995 & High \\
\hline 4 & 3 & $\begin{array}{l}\text { The administrative leader delegates some } \\
\text { responsibilities to the subordinates in accordance with } \\
\text { their readiness, abilities and experiences. }\end{array}$ & 4.09 & .996 & High \\
\hline 4 & 1 & $\begin{array}{l}\text { There is a high degree of trust between the } \\
\text { administrative leader and his subordinates at the } \\
\text { university. }\end{array}$ & 4.02 & 1.000 & High \\
\hline 6 & 5 & $\begin{array}{l}\text { The administrative leader fosters experience } \\
\text { exchange among the staff of the university. }\end{array}$ & 3.97 & 1.050 & High \\
\hline 7 & 4 & $\begin{array}{l}\text { The administrative leader respects the perspectives of } \\
\text { his subordinates even if they differed from his } \\
\text { personal one. }\end{array}$ & 3.87 & 1.103 & High \\
\hline 8 & 6 & $\begin{array}{l}\text { The administrative leader motivates his subordinates } \\
\text { to show their creativity and innovation to benefit the } \\
\text { university. }\end{array}$ & 3.85 & .961 & High \\
\hline & & Total & 4.04 & .995 & High \\
\hline
\end{tabular}

Table 6 shows that the arithmetic means achieved (3.85-4.21). Item (2) stating that "the managers have a high level of satisfaction with participative leadership and decision making on a cooperative basis" was ranked first with a high degree and an arithmetic mean of (4.21). Item (6) stating that "the administrative leader motivates his subordinates to show their creativity and innovation to benefit the university" was ranked last with an arithmetic mean of (3.85). The arithmetic mean of the whole domain was (4.04). 


\section{Bureaucratic leadership style}

Table 7. Arithmetic means and standard deviations of the items of the bureaucratic style in a descending order

\begin{tabular}{|c|c|c|c|c|c|}
\hline Rank & No. & Items & $\begin{array}{l}\text { Arithmeti } \\
\text { c mean }\end{array}$ & $\begin{array}{l}\text { Stand } \\
\text { devia }\end{array}$ & Level \\
\hline 1 & 6 & $\begin{array}{l}\text { Personal relations exist between the administrative } \\
\text { leader and his subordinates according to work. }\end{array}$ & 4.13 & .952 & High \\
\hline 2 & 5 & $\begin{array}{l}\text { Routine and bureaucracy dominate the work } \\
\text { environment. }\end{array}$ & 4.10 & 1.078 & High \\
\hline 3 & 8 & $\begin{array}{l}\text { The administrative leader prefers job obligation to } \\
\text { production. }\end{array}$ & 3.91 & 1.030 & High \\
\hline 4 & 1 & $\begin{array}{l}\text { The administrative leader tries to mechanically } \\
\text { employee his subordinates through in advance } \\
\text { definition of tasks. }\end{array}$ & 3.85 & .958 & High \\
\hline 4 & 7 & $\begin{array}{l}\text { The administrative leader fosters centralization in } \\
\text { making the administrative decision. }\end{array}$ & 3.82 & 1.022 & High \\
\hline 6 & 3 & $\begin{array}{l}\text { The effect of the external environment is neglected } \\
\text { in decision making. }\end{array}$ & 3.79 & .961 & High \\
\hline 7 & 4 & $\begin{array}{l}\text { Focusing on the ultimate application of rules and } \\
\text { regulations }\end{array}$ & 3.79 & .889 & High \\
\hline \multirow[t]{2}{*}{8} & 2 & $\begin{array}{l}\text { The administrative decision made by the leader is } \\
\text { generalizations, not details of job tasks. }\end{array}$ & 3.57 & 1.199 & High \\
\hline & & The whole domain & 3.87 & .748 & High \\
\hline
\end{tabular}

Table 7 shows that the arithmetic means achieved (3.57-4.13), item (2) indicates that "personal relations exist between the administrative leader and his subordinates according to work" was ranked first with a high degree and an arithmetic mean of (4.13). Item (2) indicates that "the administrative decision made by the leader are generalizations, not details of job tasks" was ranked last with an arithmetic mean of (3.57). The arithmetic mean of the whole domain was (3.87).

Results of the second question: Are there statistically significant differences at the level of $(\alpha=0.05)$ on the leadership styles among the administrative leaders at Najran university according to gender?

In order to answer this question, the means and standard deviations of the administrative leaders according to gender were calculated, as shown in table (8). 
Table 8. Means and standard deviations of the administrative leaders according to gender

\begin{tabular}{|l|l|l|l|l|}
\hline Style & Gender & Number & $\begin{array}{l}\text { Arithmetic } \\
\text { mean }\end{array}$ & $\begin{array}{l}\text { Standard } \\
\text { deviation }\end{array}$ \\
\hline Autocratic & Female & 63 & 3.33 & .673 \\
\cline { 2 - 5 } & Male & 54 & 2.68 & .537 \\
\hline \multirow{2}{*}{ Participative } & Female & 63 & 3.72 & .874 \\
\cline { 2 - 5 } & Male & 54 & 4.38 & .408 \\
\hline \multirow{2}{*}{ Bureaucratic } & Female & 63 & 3.97 & .536 \\
\cline { 2 - 5 } & Male & 54 & 3.75 & .928 \\
\hline
\end{tabular}

The table shows the mean differences of leadership styles among the administrative leaders at Najran University according to gender. In order to illustrate the significance of differences of the arithmetic means, T-test was adopted, as shown in table 9.

Table 9. T-test used to illustrate the significance of differences of the arithmetic means of the leadership styles among the leaders according to gender

\begin{tabular}{|l|l|l|l|l|}
\hline Style & $\mathrm{T}$ & Freedom degrees & Difference & Statistical significance \\
\hline Autocratic & 5.730 & 115 & .652 & .000 \\
\hline Participative & $-5.065-$ & 115 & $-.657-$ & .000 \\
\hline Bureaucratic & 1.611 & 115 & .222 & .110 \\
\hline
\end{tabular}

Table 9 shows that there are statistically significant differences of the leadership styles among the administrative leaders on the autocratic style in favor of females, while they favored the males in the participative leadership style. Additionally, there were no statistically significant differences in the bureaucratic leadership style.

Results of the $3^{\text {rd }}$ question: Are there statistically significant differences at the level of $(\alpha=$ 0.05 ) on the leadership styles among the administrative leaders at Najran university according to qualification?

In order to answer this question, the means and standard deviations of the administrative leaders according to scientific qualification (diploma and bachelor) were calculated, as shown in table 10. 
Table 10. Means and standard deviations of the administrative leaders according to scientific qualification

\begin{tabular}{|l|l|l|l|l|}
\hline Style & Qualification & Number & Arithmetic means & Standard deviations \\
\hline \multirow{3}{*}{ Autocratic } & Diploma & 44 & 3.23 & .901 \\
\cline { 2 - 5 } & Bachelor & 73 & 2.91 & .499 \\
\hline Participative & Diploma & 44 & 3.86 & 1.010 \\
\cline { 2 - 5 } & Bachelor & 73 & 4.12 & .565 \\
\hline Bureaucratic & Diploma & 44 & 3.93 & .649 \\
\cline { 2 - 5 } & Bachelor & 73 & 3.84 & .803 \\
\hline
\end{tabular}

Table 10 shows the means differences of leadership styles among the administrative leaders at Najran University according to scientific qualification. In order to illustrate the significance of differences of the arithmetic means, T-test was adopted, as shown in table (10).

Table 11. T-test adopted to illustrate the significance of differences of the arithmetic means of the leadership styles among the leaders according to scientific qualification

\begin{tabular}{|l|l|l|l|l|}
\hline Style & $\mathrm{T}$ & Freedom degrees & Difference & Statistical significance \\
\hline Autocratic & 2.510 & 115 & .325 & .013 \\
\hline Participative & $-1.832-$ & 115 & $-.266-$ & .070 \\
\hline Bureaucratic & .673 & 115 & .096 & .503 \\
\hline
\end{tabular}

Table 11 shows that there are no statistically significant differences among the leadership styles of the administrative leaders according to scientific qualification.

Results of the 4th question: Is there a correlation between the style and effect of leadership on the job performance behavior of the staff?

To answer this question, Pearson Correlation Coefficient was calculated for the strength and attitude of the relation between the leadership styles and job performance, as shown in table 12.

Table 12. Pearson Correlation Coefficient of the strength and attitude of the relation between the leadership styles and job performance

\begin{tabular}{|l|l|l|l|l|l|}
\hline \multicolumn{2}{|l|}{ Autocratic leadership style } & \multicolumn{2}{l|}{ Participative leadership style } & \multicolumn{2}{l|}{ Bureaucratic leadership style } \\
\hline $\begin{array}{l}\text { Pearson Correlation } \\
\text { Coefficient }\end{array}$ & Sig. & $\begin{array}{l}\text { Pearson Correlation } \\
\text { Coefficient }\end{array}$ & Sig. & $\begin{array}{l}\text { Pearson Correlation } \\
\text { Coefficient }\end{array}$ & Sig. \\
\hline$-.358^{* *}$ & .000 & $.425^{* *}$ & .000 & .010 & .912 \\
\hline
\end{tabular}

* Statistically significant at the level of $(0.01)$

The table shows that:

- There is a negative correlation between the autocratic leadership style and job performance. 
- There is a positive correlation between the participative leadership style and job performance.

- There is no correlation between the bureaucratic leadership style and job performance.

\section{Discussion and recommendations}

The present study aims to investigate the effect of leadership styles of administrative leaders on job performance behavior among staff of Najran University. The following section is a discussion of the most significant results of the study.

Discussing the results of the first question: What is the leadership style among the administrative leaders at Najran University?

The study revealed that participative style was the most prevailing one with a high degree. It was followed by the autocratic style that was high and bureaucratic style was moderate. This may be a result of the administrative development in the Saudi universities, in general, and Najran University, in particular. These universities seek to provide a suitable administrative environment that gives the staff of the university the opportunity to benefit from the employees' experience and gives them freedom of action, thinking and expressing opinions. As a result, harmony and integration are created between them and they participate in decision making. This result matches the results of many studies, e.g. Naser (2010) and Raja (2012) concluding that the democratic style positively affects job performance.

Discussing the results of the second question: Are there statistically significant differences at the level of $(\alpha=0.05)$ on the leadership styles among the administrative leaders at Najran university according to gender?

Results revealed that there are statistically significant differences in leadership styles. While differences favored the females in the autocratic leadership style, they favored the males in the participative one and there were no differences in the bureaucratic style. This may be interpreted that the females commit more to carry on their assigned administrative tasks, unlike the males who tend to participate in making the administrative decision and making initiatives towards the administrative issues at the university.

Discussing the results of the third question: Are there statistically significant differences at the level of $(\alpha=0.05)$ on the leadership styles among the administrative leaders at Najran university according to qualification?

Results revealed that there are no statistically significant differences in the leadership styles among the administrative leaders according to the scientific qualification. This may be explained that the administrators of Najran University work in a similar environment.

Discussing the results of the fourth question: Is there a correlation between the style and effect of leadership on the job performance behavior of the staff? Results revealed that:

1. There is a negative correlation between the autocratic style and job performance because this style is characterized by the focus of authorities in the hands of the person in charge, 
while the subordinates only implement the instructions. This style deprives the staff of their innovative roles because their role is only to implement.

2. There is a positive correlation between the participative style and job performance because the administrative leaders at Najran University tend to engage the employees at the different levels in planning and decision making. This helps bridge the gap between the administrative leadership and staff at the low levels by fostering the creative work and ideas. This promotes responsibility and teamwork to achieve the general objectives of the leadership. Accordingly, the performance level increases among those employees because they feel that they participate in setting the required objectives or solving the problems they face. This result matches that of Aslem (2013), showing that there is a positive correlation between the democratic style and job satisfaction. There is a negative correlation between the autocratic style and performance, but there is no correlation between chaotic style and job performance.

\section{Recommendations}

The following recommendations were made:

1- Activating the participative style because of its positive impacts on job performance.

2- Holding training courses for the administrative leaders on how to benefit from the creative energies of the staff by effectively engaging them in the administrative work.

3- Conducting more studies on leadership at other universities to have a comprehensive on the prevailing the leadership styles in the administrative work in other Saudi universities because it affects the development of the administrative work.

\section{References}

Aslem, F. (2013). The prevailing leadership styles among heads of departments at Community College in Gaza and their relationship to the staff job satisfaction (Unpublished MA. thesis). The Islamic University, Gaza.

Elalaq, B. (2009). Administrative leadership. Amman: Dar Elyazawy for Publishing and Distribution.

Elsaedy, Muayed. (2006). Organizational knowledge and memory and its impact on human resources management strategies. Unpublished $\mathrm{PhD}$ thesis, University of Baghdad, Iraq.

Elsakarna, B. (2010). Effective administrative leadership. Amman: Dar Al-Massira for Publishing, Distribution \& Printing.

Elsherief, T. (2004). The administrative leaders and their relations to job performance from the perspective of the staff in the Emirate of Makkah (unpublished MA. thesis). Naif University for Security Sciences, Riyadh. 
Hasan, M. (2004). Leadership: Bases, theories and concepts. Amman: AlKindi for Publishing and Distribution.

Kanan, N. (2009). Administrative leadership. Amman: Dar Al Thaqafa.

Khidr, Dhuha. (2009). Developing a model for practicing the areas of the learned organization from the perspective of faculty members in Jordanian universities. Unpublished $\mathrm{Ph}$. D, University of Jordan, Amman, Jordan.

Lu, Y., Junye, D., \& Yan, M. (2011). The relationships between leadership styles and organizational innovation climate: Cases of some high-tech enterprises in Hebei. https://doi.org/10.1109/ICBMEI.2011.5917910

Mullins, L. (2004) Management and organisational behavior. New Jersey: Pearson Higher Education FT Prentice Hall.

Nanjunde.T. S., \& Swamy, D. R. (2014). Leadership styles. Advances in Management, 7(2), 57-62.

Naser, H. (2010). Leadership styles and their relationship to job performance among the staff of the Palestinian private institutions from the perspective of the staff (Unpublished MA. thesis). The Islamic University, Gaza.

Omolayo, B. (2007) Effect of leadership style on job-related tension and psychological sense of community in work organizations: A case study of four organizations in Lagos State, Nigeria. Bangladesh. E-Journal of Sociology, 4(2), 32-41.

Raja, W. (2012). Does transformational leadership leads to higher employee work engagement: A study of Pakistan service sector firms. International Journal of Academic Research in Business and Social Sciences, 2(1), 160-196.

Schein, E. H. (2011). Leadership and organizational culture. New York, NY: Wiley.

Tema (2006). Decision making and the leadership behavior. Amman: Dar De Bono for Publishing and Distribution.

Whitaker, K. (2001). Where are the principal candidates? Perceptions of Superintendents. NASSP Bulletin 85(62), 82-93. https://doi.org/10.1177/019263650108562509

Wippy, H. (2001). Leadership and faculty Job satisfaction at the University of Guman (Unpublished Ph.D. dissertation). University of Nebraska-Lincoln, USA.

Yang, M. (2012). Transformational leadership and Taiwanese public relations practitioners job satisfaction and organational commitment. Social, Behavior and personality, 40(1), 31-46. https://doi.org/10.2224/sbp.2012.40.1.31

Zhang, X. and Li, B. (2013). Organizational culture and employee satisfaction: An exploratory study. International Journal of Trade, Economics and Finance, 4(1), 48-54. https://doi.org/10.7763/IJTEF.2013.V4.259 